\title{
Towards the Developing of Well Adapted Grapes for Tropical Regions
}

\author{
P.S. Ritschel, U.A. Camargo, J.D.G. Maia and L.F. Revers \\ Embrapa Uva e Vinho \\ CP 130, CEP 95.700-000, Bento Gonçalves, RS \\ Brazil
}

Keywords: Vitis, breeding, germplasm

\begin{abstract}
The association between proper pruning and irrigation practices has made it possible to grow grapes (Vitis spp.) in tropical regions. Under these conditions, however, the physiological and sanitary behavior of most commercial varieties introduced from traditional temperate regions can be quite different. As a general rule, vegetative growing and yields are not stable. Besides, production costs are also higher as a result of the adoption of an intensive program of chemical interventions. The breeding program maintained by Embrapa Grape and Wine has been using Vitis genetic variability to contribute to the solution of problems resulting from lack of adaptation of traditional grape varieties. About 3,000 hybrids from crossings between several Vitis species, including wild tropical ones, are evaluated every year. Selected individuals are multiplied and evaluated on selection fields for 3-4 years. To be sure about these results, promising selections are propagated and a greater plot is evaluated for more 3-4 years. Depending on the purpose, this step can include sensorial analysis of table grapes, juice or microvinifications. Advanced selections are then tested on real yield conditions or commercial fields, for about 2 years. New cultivars are released only when this decision is also supported by growers. Usually, grape selection prerequisites are quality for processing or table, resistance to main diseases, particularly downy mildew (Plasmopara viticola) and powdery mildew (Uncinula necator), and bud fertility. The grape breeding program is using biotechnology tools as tissue culture, especially embryo rescue for the developing of seedless table grapes, and molecular markers also. In the last years, five processing cultivars ('Moscato Embrapa', 'BRS Lorena', 'BRS Rúbea', 'BRS Cora' and 'BRS Violeta') and three seedless table cultivars ('BRS Morena', 'BRS Clara' and 'BRS Linda') released by the program are presenting good performance in tropical conditions. Currently, about 200 table and processing advanced selections are under evaluation.
\end{abstract}

\section{INTRODUCTION}

Tropical viticulture is performed in regions where the temperatures are not low enough to interrupt the grape growing (Camargo, 2003). Traditionally, viticulture is an activity carried out in temperate regions, since typical climate conditions for vinegrape development are characterized by dry summers and cold wet winters. In those conditions, the dormancy period necessary to the new cycle start is triggered by low temperatures (Sentelhas, 1998). In tropical regions, the association of irrigation control and proper plant management allows the simulation of the conditions to start the new cycle. This makes the occurrence of successive vegetative cycles possible and, as a result, the schedule of harvesting dates during the year (Camargo, 2005a). However, the physiological and sanitary performances of grape commercial varieties are entirely unlike comparing with their performance in temperate regions (Camargo, 2003).

From a physiological perspective, the main features of vinegrape growing in tropical conditions are the continuous growing, the absence of natural bud break, the irregular development of floral buds and the strong apical dominance. From a commercial perspective, this performance results in irregular growing and yields (Camargo, 2005a). Besides, in warmer conditions the behavior of the main grapevine phytopathogens, as downy mildew (Plasmopara viticola), anthracnose (Elsinoe ampelina) and powdery 
mildew (Uncinula necator), becomes remarkably aggressive. Other fungal diseases, rare or even absent in temperate regions, are problems of relative importance in tropical regions. The following plant disease agents can be pointed out: Pseudocercospora vitis, Glomerella cingulata, Phomopsis viticola, Phakopsora euvitis and Botryodiplodia theobromae. Among bacterial diseases, bacterial canker of grapevine caused by Xanthomonas campestris pv. viticola is worth mentioning, mainly because of its importance for Brazilian Northeast viticulture in the last years (Leão, 2000; Lima and Moreira, 2002).

Developing new grape cultivars is one of the approaches to withdraw some of the barriers to the progress of tropical viticulture. Some sustainable technologies have resulted from this work, which also correspond to the demand of today's consumers and farmers. New cultivars with greater fertility and/or more resistance to the major grapevine pests and diseases means the reduction of the use of chemicals on grape production, resulting in a healthy low cost product.

\section{MATERIAL AND METHODS}

Embrapa Grape and Wine is leading a hybridization program aiming at the development of new grape cultivars for table and processing (table wine and grape juice). Basic germplasm includes $V$. vinifera and $V$. labrusca, besides tropical wild species as $V$. caribaea, $V$. gigas, $V$. smalliana and $V$. schuttleworthii. Complex interspecific hybrids obtained in Europe after filoxera dissemination (for example, 'Seibel' and 'Seyve Villard', among others) and resulting from crosses between $V$. vinifera and several American species as $V$. rupestris, $V$. riparia, $V$. aestivalis, $V$. cinerea, $V$. berlandieri, $V$. bourquina and $V$. labrusca, are also used by the program, mainly as a source of main disease and pest resistance (Camargo, 1998).

Evaluations are performed at the Experimental Station of Tropical Viticulture, located at Jales, on the Northwest of São Paulo State (latitude 20 ${ }^{\circ} 16$ 'S; longitude $50^{\circ} 33^{\prime} \mathrm{W}$; altitude $483 \mathrm{~m}$ ). The climate at Jales is classified as Aw Rainy Tropical with dry winters.

Features carefully considered during initial selection include resistance to the main diseases, especially downy mildew (Plasmopara viticola) and powdery mildew (Uncinula necator), bud fertility, yield, sugar content, acidity, and flavor. Evaluation of table grapes also comprises seedless, berry adherence, size and shape of berry bunches, while selection of processing grapes contemplate the color intensity.

Biotechnological tools are used mainly on table seedless grape developing. A marker to seedless assisted selection (marker SCAR SCC8) is under validation (Revers et al., 2005). On the other side, embrio rescue is a routine procedure for seedless grape breeding (Amaral et al., 2000).

About 3,000 hybrids, resulting from crosses between the species mentioned above, are evaluated each year. Selected individuals are propagated to selection fields, where they are evaluated during 2-3 years. Promising selections are then propagated to validation fields where the worth of each selection is judged for another 3-4 years. Depending on the selection's purpose, this evaluation step can include sensorial analysis of table grapes or microvinifications. Advanced selections are then tried on farmer's fields for about two years. New cultivars are released only when farmers support this decision.

\section{RESULTS AND DISCUSSION}

In the last years, nine new grape cultivars adapted to tropical conditions were developed and released by Embrapa Grape and Wine, including seedless table grapes and also juice and table wine grapes. High yields and resistance/tolerance to the main grape diseases as downy and powdery mildew are the main features of these cultivars.

\section{'Moscato Embrapa' \\ 'Moscato Embrapa' was obtained from a 'Couderc 13' × 'July Muscat' cross. This}


white late grape is also resistant to fungal diseases, mainly bunch rot. Its wine is described as aromatic, with a soft muscat flavor and low acidity, which is prefered by Brazilian consumers. At maturity, the grape can reach up to $19^{\circ} \mathrm{Brix}$. It is recommended to limit yields to about $35 \mathrm{t} / \mathrm{ha}$, assuring grape proper maturation and therefore the wine quality. It has good performance in Brazilian tropical conditions (Camargo and Zanus, 1997).

\section{'BRS Lorena'}

'BRS Lorena' resulted from a cross between 'Malvasia Bianca' and 'Seyval' and can be used to make a muscat sparkling wine, mainly because of its high sugar level (more than $20^{\circ}$ Brix) and acidity $(90-100 \mathrm{meq} / \mathrm{L}$ ). It can reach yields of about $30 \mathrm{t} / \mathrm{ha}$. It is very resistant to fungal diseases, especially to bunch rot, but in some years filoxera occurrence can become a problem. It results in a muscat table wine or in muscat sparkling wine with foam and persistent perlage. It has good performance in tropical regions (Camargo and Guerra, 2001).

\section{'BRS Rúbea'}

'BRS Rúbea', obtained from the cross 'Niágara Rosada' × 'Ives Seedling', is a typical "teinturier" or dyer red grape, for use primarily in juice blends with 'Isabel' and 'Concord'. It can also be used to make table wines. The bunch is small, $100 \mathrm{~g}$ on average, $19 \mathrm{~mm}$ berry, and $15^{\circ}$ Brix. It is vigorous, disease resistant and well adapted to Brazilian Southern conditions. It yields about $20 \mathrm{t} / \mathrm{ha}$. Although having some problems when growing in hot climates, this cultivar is being grown in Goias State as an alternative to dyer red grapes (Camargo and Dias, 1999).

\section{'BRS Cora'}

'BRS Cora' is a high-yield red cultivar producing grape juice with excellent color and high levels of sugar (18-20 Brix) . It is a result of a 'Muscat Belly A' × 'BRS Rúbea' cross. It is moderately vigorous, with determinate growth habit. It was released as an alternative to the production of juice and table wine in tropical regions to increase the color of 'Isabel' and 'Isabel Precoce' products. It can also be grown in Brazilian Southern temperate climate. Protected cultivar (Camargo and Maia, 2004).

\section{'BRS Violeta'}

Hybrid grape, resulting from 'BRS Rúbea' and 'IAC 1398-21' cross, it includes vinifera and labrusca germplasm. It is very fertile (25-30 t/ha) and proper to elaborate juice and table wine. It is adapted to a range of climates, and can be grown in the Brazilian South and also in tropical regions as the Northwest of São Paulo Sate and Mato Grosso. Its major advantage is the excellent quality, which results from the combination of high sugar levels (19\% brix) and the juice's intense violet color. Protected cultivar (Camargo et al., 2005).

\section{'BRS Clara'}

Seedless yellowish, almost golden, grape, adapted to Brazilian tropical regions. It was obtained from the 'CNPUV 154-147' and 'Centennial Seedless' cross. It is very fertile under natural conditions and very productive (25-30 t/ha) and with a high sugar potential, easily reaching $20^{\circ}$ Brix. Bunches are great, naturally loose, and the berries reach $17 \mathrm{~mm}$ upon giberellic acid use, having a slight muscat flavor. Disease behavior is similar to 'Itália', but 'BRS Clara' presents tolerance to bacterial canker (Xanthomonas campestris pv. viticola). Protected cultivar (Camargo et al., 2003a).

\section{'BRS Linda'}

Seedless white or light green grape, adapted to Brazilian tropical conditions. Berry diameter is $22 \mathrm{~mm}$ upon giberellic acid use - which is particularly large for a white seedless variety. 'BRS Linda' is a seedling of a 'CNPUV 154-90' and 'Saturn' cross. Yields are very high yields (30-35 t/ha); sugar content (14-15 ${ }^{\circ}$ Brix) and acidity are low, 
resulting in a pleasant neutral flavor. Bunches are great and loose, berry thinning being unnecessary. It is highly resistant to berry drop. Disease behavior is similar to 'Itália', but 'BRS Linda' is particularly susceptible to powdery mildew. Protected cultivar (Camargo et al., 2003b).

\section{'BRS Morena'}

Seedless black grape, developed for tropical Brazilian conditions; resulting from the 'Marroo Seedless' $\times$ 'Centennial Seedless' cross. It is highly fertile and productive (20-25 t/ha). Bunches are very loose and proper management is necessary to obtain adequate fruit set. Berries can reach $20 \mathrm{~mm}$ diameter (upon giberellic acid), having crunchy texture. Sugar content is high $\left(18-19^{\circ}\right.$ Brix $)$ and the flavor is pleasant. It is very sensitive to berry drop, then it requires proper packaging. Disease behavior is similar to 'Itália'. Protected cultivar (Camargo et al., 2003c).

\section{CONCLUSIONS}

Association between conventional genetic breeding and biotechnological tools has been very successful in developing new tropical grape cultivars. Currently, about 200 table and processing grape selections are under evaluation and about 15 advanced selections are under validation. This points to the perspective of development and release of new tropical grapes in the next years.

\section{Literature Cited}

Camargo, U.A. 1988. Grape breeding for the subtropical and tropical regions of Brazil. In: Symposium International sur la Genetique et l'Amelioration de la Vigne, 7., 1998, Montpellier. Resumenes (communications orales). Montpellier: INRA: AgroMontpellier: ENTAV, 1998. Abstract C4.19.

Camargo, U.A. 2003. A produção vitícola nas regiões tropicais do Brasil: colheita de uva todo o ano. In: Jornadas del Gesco, 13., 2003, Montevideo. Libro de actas: Gesco 2003, Uruguay. Montevideo: Gesco, 2003. p.142-143.

Camargo, U.A. 2005. Grape management techniques in tropical climates. In: International Gesco Viticulture Congress, 14., 2005, Geisenheim, Germany. Proceedings. Geisenheim: GESCO, 2005a. v. 2, p.251-256.

Camargo, U.A. and Dias, M.F. 1999. 'BRS Rúbea'. Bento Gonçalves: Embrapa Uva e Vinho. 4p. (Embrapa Uva e Vinho. Comunicado Técnico, 33).

Camargo, U.A. and Guerra, C.C. 2001. 'BRS Lorena': cultivar para elaboração de vinhos aromáticos. Bento Gonçalves: Embrapa Uva e Vinho. 4p. (Embrapa Uva e Vinho. Comunicado Técnico, 39).

Camargo, U.A. and Maia, J.D.G. 2004. 'BRS Cora': nova cultivar de uva para suco, adaptada a climas tropicais. Bento Gonçalves: Embrapa Uva e Vinho. 4p. (Embrapa Uva e Vinho. Comunicado Técnico, 53).

Camargo, U.A. and Zanuz, M.C. 1997. EMBRAPA 131 - 'Moscato Embrapa': nova cultivar para a elaboração de vinho branco. Bento Gonçalves: EMBRAPA-CNPUV. 4p. (EMBRAPA-CNPUV. Comunicado Técnico, 24).

Camargo, U.A., Maia, J.D.G. and Nachtigal, J.C. 2005. 'BRS Violeta': nova cultivar de uva para suco e vinho de mesa. Bento Gonçalves: Embrapa Uva e Vinho. 8p. (Embrapa Uva e Vinho. Comunicado Técnico, 63).

Camargo, U.A., Nachtigal, J.C., Maia, J.D.G., de Oliveira, P.R.D. and Protas, J.F. da S. 2003a. 'BRS Clara': nova cultivar de uva de mesa branca sem semente. Bento Gonçalves: Embrapa-CNPUV. 4p. (Embrapa Uva e Vinho. Comunicado Técnico, 46).

Camargo, U.A., Nachtigal, J.C., Maia, J.D.G., de Oliveira, P.R.D. and Protas, J.F. da S. 2003b. 'BRS Linda': nova cultivar de uva de mesa branca sem semente. Bento Gonçalves: Embrapa-CNPUV. 4p. (Embrapa Uva e Vinho. Comunicado Técnico, 48).

Camargo, U.A., Nachtigal, J.C., Maia, J.D.G., de Oliveira, P.R.D. and Protas, J.F. da S. 2003c. 'BRS Morena': nova cultivar de uva de mesa preta sem semente. Bento Gonçalves: Embrapa-CNPUV. 4p. (Embrapa Uva e Vinho. Comunicado Técnico, 47). 
de Amaral, A.L., de Oliveira, P.R., Camargo, U.A. and Czermainski, A.B.C. 2000. Eficiência da técnica de resgate de embriões na obtenção de híbridos entre cultivares apirênicas de vidiera. Revista Brasileira de Fruticultura 22:176-180.

Leão, P.C. de S. and Soares, J.M. (eds.). 2000. A Viticultura no semi-árido brasileiro. Petrolina, PE: Embrapa Semi-árido. 366p.

Lima, M.F. and Moreira, W.A. (eds.). 2002. Uva de mesa: fitossanidade. Brasília, DF: Embrapa Informação Tecnológica. 75 p. (Embrapa Informação Tecnológica. Frutas do Brasil, 14).

Revers, L.F., Lampe, V.S., de Oliveira, P.R.D., Camargo, U.A. and Lima, J.C. 2005. Uso prático de marcadores moleculares para seleção assistida no melhoramento de uvas de mesa apirênicas. Revista Brasileira de Fruticultura 28:12-17.

Sentelhas, P.C. 1998 Aspectos climáticos para a viticultura tropical. Informe Agropecuário 19(194): 9-14. 


\section{Figures}

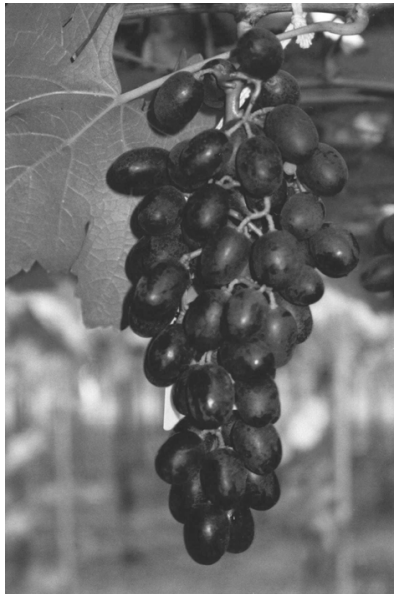

A

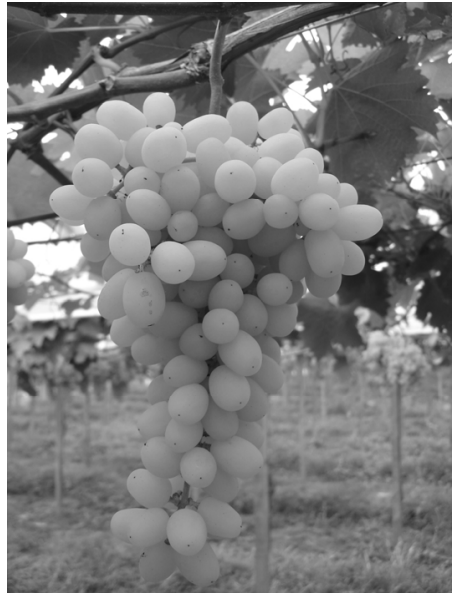

B

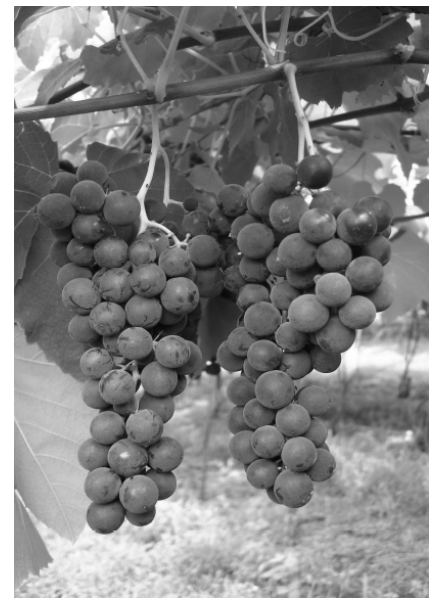

$\mathrm{C}$

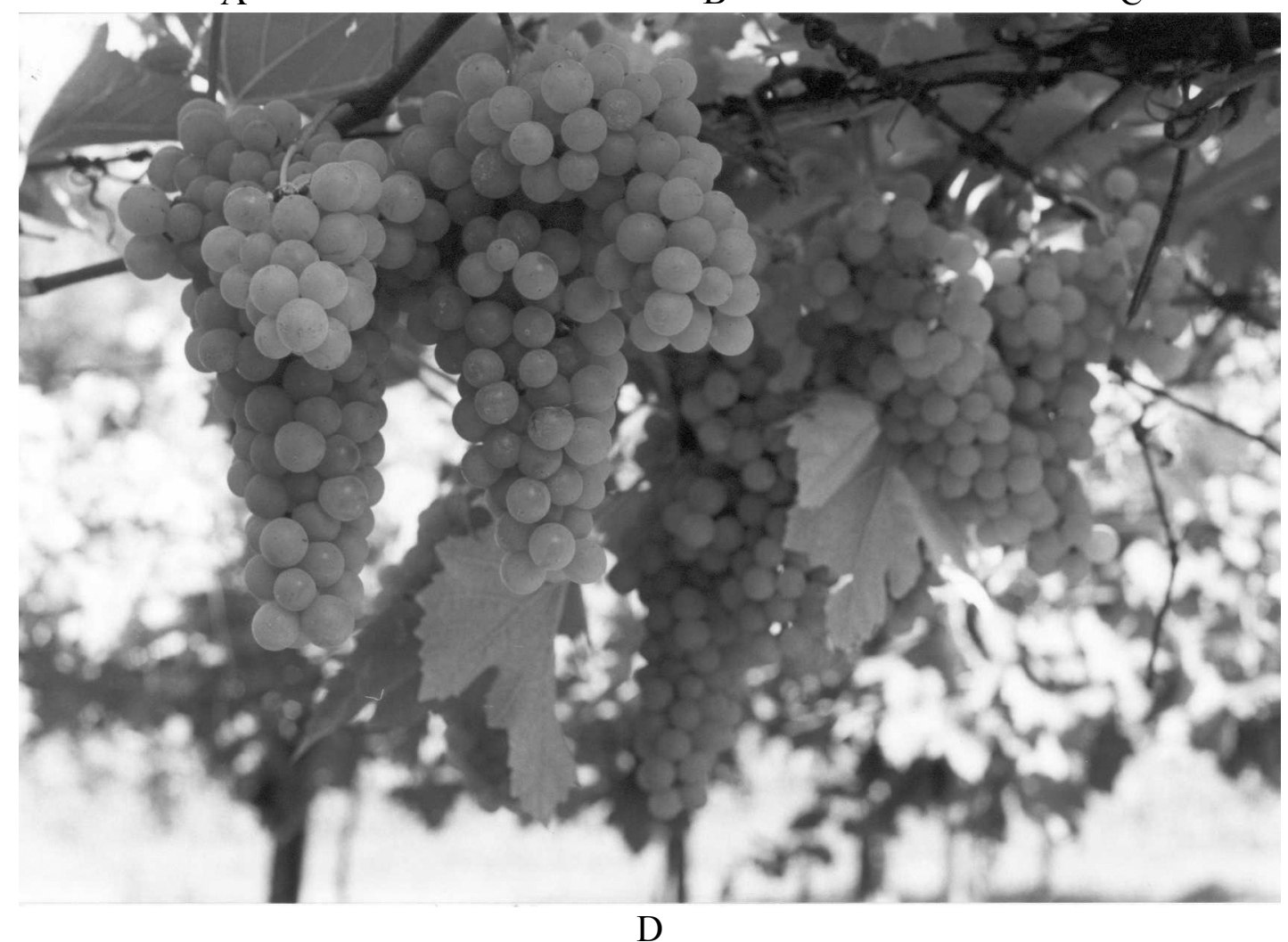

Fig. 1. Some tropical grape cultivars, developed by the Grape Breeding Program (Embrapa Grape and Wine): (A) 'BRS Morena', seedless table grape; (B) 'BRS Clara', seedless table grape; (C) 'BRS Violeta', dyer red grape for processing; (D) 'BRS Lorena', muscat white grapes for processing. 